\title{
Ecosystem Learning with Sparkol Videoscribe-Based Learning Media
}

\section{Luh Eka Ratna Widiari1*, I Gede Astawan²}

\footnotetext{
1,2 Program Studi Pendidikan Guru Sekolah Dasar, Universitas Pendidikan Ganesha
}

\section{A R T I C L E I N F O}

Article history:

Received March 07, 2021

Revised March 08, 2021

Accepted May 07, 2021

Available online May 25, 2021

\section{Kata Kunci:}

Pengembangan, Media

Pembelajaran, Sparkol

Videoscribe , Ekosistem

Keywords:

Development, Learning Media, Sparkol Videoscribe, Ecosystem

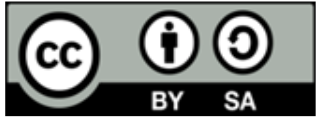

This is an open access article under the CC BY-SA license.

Copyright $(2021$ by Author. Published by Universitas Pendidikan Ganesha.

\begin{abstract}
A B S T R A K
Penelitian ini didasari rendahnya hasil belajar yang disebabkan oleh kurangnya pemanfaatan media pembelajaran yang kratif dan inovatif. Penelitian ini bertujuan untuk menciptakan rancangan bangun media dan menghasilkan produk media pembelajaran berbasis sparkol videoscribe pada topik ekosistem kelas V sekolah dasar yang telah teruji validitasnya. Penelitian pengembangan ini menggunakan model penelitian 4D. Subjek uji coba penelitian pengembangan ini yaitu 2 orang dosen ahli isi mata pelajaran, 2 orang dosen ahli desain pembelajaran, 2 orang dosen ahli media, dan 1 orang guru kelas $V$ serta 9 orang siswa. Metode pengumpulan data yang digunakan dalam penelitian pengembangan ini yaitu metode kuisioner berupa instrumen rating scale skala empat yang diberikan kepada subjek uji coba. Hasil rata-rata skor dari ahli isi mata pelajaran sebesar 3,81 dengan kualifikasi sangat baik, hasil rata-rata skor ahli desain pembelajaran sebesar 3,68 dengan kualifikasi sangat baik dan rata-rata skor dari ahli media pembelajaran sebesar 3,79 dengan kualifikasi sangat baik. Kemudian dari hasil penilaian guru diperoleh rata-rata keseluruhan sebesar 3,90 dengan kualifikasi sangat baik. Data hasil uji coba perorangan diperoleh rata-rata sebesar 3,89 dengan kuaifikasi sangat baik dan data hasil uji coba kelompok kecil diperoleh ratarata sebesar 3,94 dengan kualifikasi sangat baik. Berdasarkan hasil analisis uji validitas oleh ahli dan guru, media pembelajaran berbasis sparkol videoscribe pada topik ekosistem kelas $V$ sekolah dasar dinyatakan valid dan layak digunakan dalam pembelajaran.
\end{abstract}

\begin{abstract}
A B S T R A C T
This research is based on the low learning outcomes caused by the lack of use of creative and innovative learning media. This study aims to create a media building design and produce learning media products based on sparkol videoscribe on the topic of the fifth grade elementary school ecosystem that has been tested for its validity. This development research uses a 4D research model. The subjects of this development research trial were 2 subject content expert lecturers, 2 instructional design expert lecturers, 2 media expert lecturers, and 1 grade $V$ teacher and 9 students. The data collection method used in this development research is a questionnaire method in the form of a four-scale rating scale instrument given to the test subjects. The average score of subject content experts is 3.81 with very good qualifications, the average score of learning design experts is 3.68 with very good qualifications and the average score of learning media experts is 3.79 with qualifications very good. Then from the results of the teacher assessment obtained an overall average of 3.90 with very good qualifications. Data on the results of individual trials obtained an average of 3.89 with very good qualifications and data from small group trials obtained an average of 3.94 with very good qualifications. Based on the results of the analysis of the validity test by experts and teachers, learning media based on sparkol videoscribe on the topic of the fifth grade elementary school ecosystem is declared valid and suitable for use in learning.
\end{abstract}

\section{INTRODUCTION}

Currently the world is being hit by a disease caused by a virus which not only affects one region, the virus is the coronavirus disease 2019 or often referred to as COVID-19. Coronavirus diseases 2019 or COVID-19 is a new type of disease that has never been previously identified by humans (Miani, et al., 2021; A. Purwanto et al., 2020). The impact of this disease outbreak does not only affect several sectors of human life but also all sectors, including the education sector (Jowsey et al., 2020; Qazi, Hardaker, et al., 2021) The impact that is most felt by this pandemic is the implementation of online or distance learning where the learning process is carried out at home (Dewi, 2020; Qazi, Qazi, et al., 2021). Learning carried out in elementary schools also uses online or distance learning. The peak period of the COVID-19 pandemic forced more than 1.6 billion children to study online while being guided by their parents (Kaffenberger, 2021). Online learning or distance learning uses the use of internet networks in the learning process and remains in accordance with the curriculum used. The current curriculum used at the primary school level is the 2013 Curriculum with an integrated thematic approach, namely learning that 
links one subject to another according to the theme. One theme consists of basic competencies and indicators covering several different subjects. One of the subjects used in the theme network in thematic learning is Science. Science is a science that explores the universe and its contents, the events that occur in it (Harapan, 2020; Nana, 2013). Science education in elementary schools is expected to be a vehicle for students to learn about themselves and the natural surroundings, as well as the prospect of further development in applying it in everyday life. (Samari et al., 2020). The science learning process must emphasize providing direct experience by students to develop competence to explore and understand the natural surroundings, which in the end they find themselves the concept of the subject matter being studied (Andriana et al., 2020).

It is felt that the provision of direct learning through observations in the environment in online learning is not entirely sufficient in the science learning process, given the limited scope of learning material in student books and the limited learning time. In addition, there are challenges in learning science during the COVID-19 pandemic faced by students, including limited communication and socialization between students so that memorable learning that should be obtained when science learning cannot be carried out optimally (H. Purwanto et al., 2020). To overcome these limitations, it is necessary to have a learning media that can help a learning process and become an intermediary for the delivery of material. In delivering science learning, a facility is needed that can deliver learning materials in the form of models and appropriate learning tools (Rahayu et al., 2012). Learning media can be used as an intermediary between teachers and students in understanding learning to make it more effective and efficient (Fransisca \& Mintohari, 2018; Hillmayr, et al., 2020). The use of learning media also has an important role in the teaching and learning process, in addition to being a communication tool, the delivery of material through learning media can also attract students' attention. This is also stated in the previous research that learning media make students happy, interested, and enthusiastic during the learning process and also the maximum learning outcomes can be obtained (Kurniawan \& Trisharsiwi, 2016). By attracting students' attention, learning can create an interesting, fun, creative and innovative learning environment. Learning with a pleasant atmosphere can make students better understand the material being taught and their memory about the material being taught or learning is more memorable. In addition, with the existence of learning media, the complexity of the teaching materials to be delivered can be simplified with the help of learning media so that students understand the learning material faster. (Batubara, 2017). There are several types of learning media, namely learning media in visual form, learning media in audio form, and learning media in audio visual form (Kustandi \& Sutipto, 2013). Lowthwer \& Rusell divides media into six types, namely text media, audio media, visual media, video, manipulative and people. Text media are alphaneumeric characters that can be displayed in any form such as books, posters, whiteboards, and computer screens and so on (Loren at al., 2017). There are six categories, namely non-projected media, projected media, audio media, film media and communication media. All types of learning media have their respective advantages and disadvantages (Muhson, 2010).

In fact, what happens in the learning process based on the results of observations and interviews conducted, the use of learning media in the learning process is still not optimal. Where teachers at school provide more material in student books or teacher books or provide learning material through videos obtained through YouTube. This is because the making of learning media is considered very complicated and requires a long time, especially the creation of learning media with complex learning content as in the topic of learning science. In addition, in the observation process, where students will be more interested and enthusiastic in learning if the learning is conveyed through learning media in the form of instructional videos, moreover, learning currently applied is online learning, so that the existence of this learning media will greatly help students in understanding the material learning. Apart from the results of observations, previous research also stated that the use of learning media in schools was not maximal (Windiyani et al., 2018). The use of learning media has not been maximized, making students bored and not interested in learning. The importance of using instructional media is highlighted in research which states that the learning media makes students happy, interested and enthusiastic during the learning process and the maximum learning outcomes can be obtained (Kurniawan \& Trisharsiwi, 2016). Based on the above, it is necessary to develop learning media in the form of learning videos that are innovative, creative and easy to manufacture, namely by making learning videos assisted by an application called Sparkol videoscribe. Sparkol videoscribe is an application for making video media with the concept of a blackboard that uses hand drawings and seems to be drawing or writing on the blackboard (Afifah \& Hidayat, 2018; Silmi \& Rachmadyanti, 2018). Sparkol videoscribe is an animated video learning media consisting of a series of images arranged into a complete video (Azizah, 2018). With the sparkol videoscribe, it intends to focus on the boundaries of learning activities to be more efficient and successful, simplify knowledge, not only material but also explanations that are poorly understood by students as well as materials that require audio accuracy (Latifah et al., 2020; Nurromah et al., 2018). In addition, the sparkol videoscribe media is a 
visual aid that can help academics, educators and learning practitioners in facing educational challenges that are increasingly developing in accordance with the demands of the times (Herlin et al., 2020). Besides having the advantage of being able to combine images, sounds and attractive designs, Sparkol Videoscribe also has advantages where the features provided in various applications can also be tailored to the needs and characteristics of these students (Adabiyah \& Agustina, 2018). With the existence of sparkol videoscribe based learning media students can learn independently and this will also attract students' attention more with the material written on the video, especially if it is added to the voice of explanation by the teacher who made the video which will make learning more enjoyable and also more memorable (Nurromah et al., 2018). Based on this, it can be concluded that Sparkol Videoscribe-based learning media as a learning medium that is innovative, creative and easy to manufacture so that it can help and motivate students in learning. Based on the explanation above, the researcher wants to develop sparkol videoscribe-based learning media on the topic of class $\mathrm{V}$ ecosystem. With the development of sparkol videoscribe based learning media on the topic of elementary school grade V ecosystems, it can help students to understand learning materials, especially on the topic of ecosystems and help teachers to be able to explain. learning materials creatively and innovatively. Thus the researcher initiated a study entitled "Development of Learning Media Based on Sparkol Videoscribe on the Ecosystem Topic of Class V Elementary Schools".

\section{METHOD}

This research is a development research that develops learning media based on sparkol videoscribe whose validity has been tested. This research was conducted in October - March 2021. The model used in this study is the 4D model (Define, Design, Develop and Desseminate). The 4D model is a systematic learning design model. The selection of the 4D development model is based on systematic considerations and is based on the theoretical foundation of learning. This development model is structured programmatically with a systematic sequence of activities in an effort to solve learning problems related to learning resources tailored to the needs and characteristics of learners (Arywiantari et al., 2015). The 4D development model consists of four stages, namely: (1) the defining stage; (2) the design stage; (3) the development stage; and (4) the dissemination stage ( Syafri, 2018).

The trial subjects in this study were two subject content expert lecturers, two instructional design expert lecturers, two media expert lecturers, one teacher and nine students. While the object of this research is the validity of learning media based on sparkol videoscribe on the topic of the fifth grade elementary school ecosystem. The type of data used in this study consists of two types of data, namely qualitative data and quantitative data. Qualitative data is a type of data that is presented in the form of words in the form of responses, input, criticism and suggestions. While quantitative data is a type of data in the form of scores obtained based on the results of media assessments conducted by providing validation sheets for learning media by experts, teachers and students. The data collection method used in this research is the observation method, namely the method of data collection which is carried out by systematically direct observation of the object under study. In this study, the observation was carried out by observing the learning process online. Furthermore, the data collection method used is the interview method, namely by conducting question and answer systematically and the results of the questions and answers that have been done are recorded or recorded carefully (Agung, 2014). The questionnaire method is a method of collecting data by collecting data by sending a list of questions or statements to respondents or research subjects (Agung, 2017).

The data collection instrument in this study was a questionnaire or a questionnaire. According to Arikunto, what is meant by data collection instruments is a tool chosen in collecting data so that the data obtained in these activities becomes systematic and easy in data processing (Fadilah, 2016). The use of questionnaires in this study was to collect data from reviews from instructional design experts, subject areas, instructional media, practitioners or teachers and the results of reviews conducted by students. In the questionnaire or questionnaire used in collecting the research data using a rating scale type. Rating scala is a scoring technique using a certain scale on which to base your assessment from the lowest level to the highest level. With the use of the rating scale raw data obtained from data collection in the form of numbers is then interpreted in a quantitative sense (Triana \& Widyarto, 2013). The answer scale used in the rating scale is given a score so that quantitative analysis can be carried out such as (1) Very Good (SB) / Strongly Agree (SS) is given a score of 4; (2) Good (B) / Agree (S) is given a score of 3; (3) Poor (KB) / Disagree (KS) is given a score of 2; and (4) Not good (TB) / Disagree given a score of 1 . The instrument used in this study was tested for the validity of the instrument to examine the validity of each item of the instrument with the results of the content validity of 1.00 with very valid qualifications and reliability 
tests. instrument to determine the consistency of the instrument used so that it can be said to be a good instrument with a degree of reliability of 1.00 with very reliable qualifications.

The data analysis methods and techniques used in this research on the development of learning media based on sparkol videoscribe are descriptive statistical analysis and quantitative descriptive statistical analysis. The qualitative descriptive statistical analysis method is used to process data from the review results in the form of input, criticism and suggestions given by learning material experts in this case, namely experts in science subjects, learning design experts, learning media experts as well as individual and small group reviews conducted by students on Learning media based on sparkol videoscribe by providing an assessment sheet of the learning media. Quantitative statistical analysis methods are used to describe the average score of each science learning material expert, learning design expert, instructional media expert and individual tests carried out related to the developed learning media. The score that has been obtained from each of the assessment indicators is then calculated on average to determine the validity of the learning media.

\section{RESULT AND DISCUSSION}

\section{Result}

First, the define stage consists of five main steps, namely (1) front-end analysis, (2) student analysis, (3) concept analysis, (4) task analysis and (5) formulation of learning objectives. The results of the early-final analysis stage are that the problem faced is the lack of use of instructional media in the learning process so that it still uses the lecture method and takes material directly in student books. In addition, the results obtained at this stage are the lack of material sources or supporting material on the topic of ecosystems so that the material that can be delivered is limited. Then the results of the student analysis showed that students were more enthusiastic in participating in learning if the learning was packaged creatively and creatively and using concrete examples in accordance with the developmental characteristics of grade $\mathrm{V}$ students at the concrete operational stage. Then the results of the concept analysis stage show that the material in the developed learning media is based on the competencies (KD) and indicators that have been developed. The results of the task analysis carried out were the main skills needed in learning activities, namely reading, listening and listening skills in accordance with the basic competency analysis on more specific sub-indicators. Furthermore, the results of the preparation of objectives, namely learning objectives are arranged according to formulated indicators so that the learning materials arranged in the learning media are in accordance with the learning objectives. Based on the five analyzes in the define stage, the researcher developed a sparkol videoscribe-based learning media on the topic of the ecosystem for fifth grade elementary school.

Second, the design stage is carried out by compiling media assessment instruments and compiling designs for making learning media products based on sparkol videoscribe. The instruments compiled in this development research consist of validation instruments for subject content experts, validity instruments for learning design experts, instruments for media experts and instruments for individual and group testing. At this stage, it is also carried out to compile a design for making learning media products based on sparkol videoscribe. Third, the development stage is carried out by making the media in accordance with the building design that has been compiled in the storybord that has been approved by the supervisor. This media development consists of four stages, namely the initial product development stage, the product appraisal stage, the product revision stage and the final product development stage. The initial product development stage is carried out by making the media in accordance with the building design that has been made in accordance with the storyboard and media creation script. After the initial product is consulted with the supervisor for advice and input, the next stage is the initial product assessment stage. The results of the development of learning media based on sparkol videosribe on the topic of the ecosystem are shown in Figure 1, Figure 2, and Figure 3.

This initial product assessment stage is carried out to determine the validity of the product being developed. The validity test of this product was carried out by two content experts in learning materials, two learning design experts, two instructional media experts, one class $\mathrm{V}$ teacher, and nine grade $\mathrm{V}$ students. The learning media validity test score that has been obtained from each indicator is then calculated the average value. The average score obtained is then converted using the four scale conversion guidelines. The results of the validity of sparkol videoscribe based learning media on the topic of the fifth grade ecosystem by subject content experts, learning design experts, instructional media experts, teachers and individual and small group trials in more detail can be presented in Table 1. 


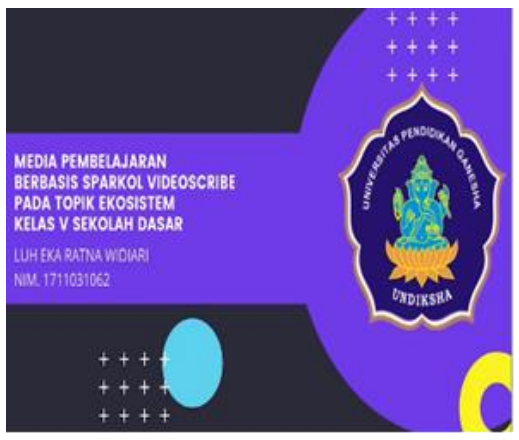

Figure 1. Coverpage Slide

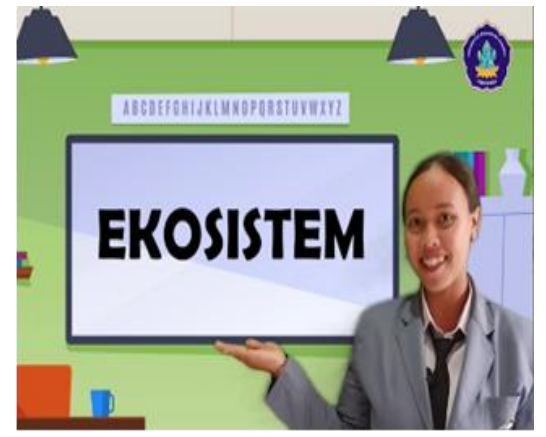

Figure 2. Topic Slide

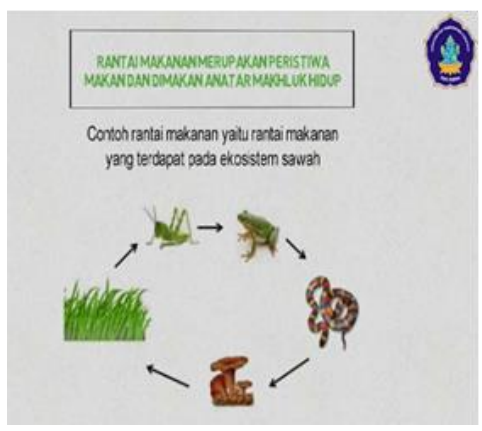

Figure 2. Material/Content Slide

Fourth, the dissemination stage, namely by distributing sparkol videoscribe-based learning media on the topic of elementary school fifth grade ecosystems through the Youtube platform, so that later teachers and students access sparkol videoscribe-based learning media on the topic of the fifth grade elementary school ecosystem both for direct learning and online so that it helps increase understanding of ecosystem topics in the learning process.

Tabel 1. Results of Validity of Learning Media Based on Sparkol Videoscribe

\begin{tabular}{lll}
\hline Trial Subject & Average Score & Qualification \\
\hline Subject Content Expert Test & 3,81 & Very good \\
Learning Design Expert Test & 3,68 & Very good \\
Learning Media Expert Test & 3,79 & Very good \\
Media Test by the Teacher & 3,90 & Very good \\
Individual Trial & 3,89 & Very good \\
Small Group Trial & 3,94 & Very good \\
\hline
\end{tabular}

\section{Discussion}

Based on the five analyzes in the define stage, it is very necessary to develop a learning media based on sparkol videoscribe on the topic of the fifth grade elementary school ecosystem. Based on the results of preliminary analysis, concept analysis, student analysis and concept analysis, it is explained that in science learning, a learning media is needed that can help students understand science learning material, especially in online learning conditions that require students to learn independently (Handayani, 2021). This is because in science learning emphasizes direct experience for students to develop their potential so that they are able to understand the natural surroundings so as to foster cognitive, psychomotor, and social skills (Prabowo, 2015). In addition, based on the results of the definition stage, students will be more motivated to learn if the learning process is useful and is packaged in a more creative and varied manner. Online learning or learning through various online media does not only present material in the form of writing but such as the addition of video or audio (Putria et al., 2020).

The design stage was carried out by compiling media assessment instruments and compiling designs for making learning media products based on sparkol videoscribe. The validation instrument that has been designed has been tested for the validity of the instrument and the test for the reliability of the instrument. Based on the results of the instrument validity test and the instrument reliability test that has been carried out, the validity test and reliability test results are very high. The design of the building or the design of learning media based on sparkol videoscribe on the topic of the fifth grade elementary school ecosystem consists of a storyboard and a script design for making learning media. This learning media is designed with a duration of 9-12 minutes and makes opening and closing or opening and closing in the Adobe Premiere Pro CC 2018 application and making learning materials on ecosystem topics using the help of a videographic application, namely Sparkol Videoscribe. The storyboard consists of an initial picture or sketch in each scene from the learning media being developed. Then the draft of the manuscript contains a narrative which in this case is the material that will be displayed in sparkol videoscribe-based learning media for grade $\mathrm{V}$ elementary schools. Learning media based on sparkol videoscribe-based learning that has been developed is different from the learning media that has been developed by packaging the learning media in a concise manner and with varying text colors. In addition, the sparkol videoscribe-based learning media developed is equipped with clear voice dubbing that will help students 
understand the material presented and coupled with background music that will increase students' enthusiasm for learning.

Based on the results of the development stage learning media based on sparkol videoscribe on the topic of ecosystem is declared valid. Based on the results of assessments conducted by subject content experts, it shows that the sparkol videoscribe-based learning media on the topic of ecosystems is very good. This is because learning media based on sparkol videoscribe on the topic of the ecosystem which is developed from the aspect of the material structure presented is very precise, the accuracy of the material in the learning media is very accurate, the use of grammar and writing in learning media is very good and the level of difficulty of the material presented is appropriate. with user characteristics. This finding is in line with the research conducted by Fransisca, et al (2018) The questionnaire results of the material validation were very good, as well as the sparkol videoscribe-based learning media that was developed very feasible in the science learning process in the solar system material and there was an increase in student learning outcomes. In addition, with the existence of sparkol videoscribe-based learning media, students can understand the learning material well and can make students focus on learning (Adabiyah \& Agustina, 2018; Handayani, 2021; Nurromah et al., 2018). The input provided by subject content experts and teachers who provide an assessment of the aspects of the learning content, namely the learning media is in accordance with the material discussed, but KD and indicators have not been seen in the video and there is a typo in the word "peptisida" so that improvements have been made to the product. learning media by adding basic competencies and indicators and correcting errors in writing the word "pestisida".

Then the results of the assessment carried out by learning design experts show that the sparkol videoscribe-based learning media on the topic of ecosystems is very good. This is because learning media based on sparkol videoscribe on the topic of ecosystems are developed from the aspect of the accuracy of learning objectives, the suitability of videos with student characteristics is very good. In addition, learning media based on sparkol videoscribe on the topic of ecosystems that are developed from the aspect of learning methods are very good, learning media can attract students' learning interest and attention and learning media developed can have an impact on students based on these aspects. This finding is in line with research obtained are that based on the results of material validation, media, and learning media design based on sparkol videoscribe can attract students' interest in learning and have the effect of increasing student learning outcomes (Afifah \& Hidayat, 2018). In addition, the use of learning media can help students focus on listening to learning (Adabiyah \& Agustina, 2018; Novita, et al., 2019). As for the input provided by subject content experts and teachers who provide an assessment of the learning design aspect, it is necessary to add a mind map so that students can more easily understand what material will be studied in the learning media so that improvements have been made by adding a mind map to the learning media.

Based on the results of the assessment conducted by instructional media experts, it shows that the sparkol videoscribe-based learning media on the topic of ecosystems is very good. This is because the learning media based on sparkol videoscribe on the topic of the ecosystem which is developed from the aspect of visual quality is very good, the sound presented in the learning media is very clear, the learning media in presenting the learning videos are very suitable and in the learning media the pouring of ideas for learning media is very creative. This finding is in line with research that is, based on the results of visual attractiveness in the developed learning media, it provides an increase in the average student learning outcomes (Fransisca \& Mintohari, 2018). Besides that, it is in line with research namely aspects of appearance, presentation of material, benefits and application of the sparkol videoscribe learning media developed which is very helpful in improving students' understanding in learning (Silmi \& Rachmadyanti, 2018). The input provided by instructional media experts and teachers who provide an assessment of the aspects of the learning content, namely by varying the color of the text so that students are more interested and not boring, so that improvements have been made by varying the color of the text in the learning media.

The results of the media validity test conducted by the teacher were very good in terms of the content of the subjects, learning design and learning media based on sparkol videoscribe very well. Then the results of the individual trial assessment that took six students obtained that the overall individual trial was very good and the results of the group trial of sparkol videoscribe-based learning media were very good. This is because the learning media based on sparkol videoscribe on the topic of the developed ecosystem really attracts students 'attention, the presentation of material on the developed learning media so that it is easily understood by students, the learning media attracts students' attention. Then in the aspect of motivating students so that the learning media that is developed can motivate students in learning and the clarity of the voice in the learning media is very clear. This finding is in line with the research that is, there is an increase in student learning interest and attention by using sparkol videoscribe-based learning media so that there is an increase in student learning outcomes on the small- 
scale test carried out in the study (Fransisca \& Mintohari, 2018). The appearance of learning media has an influence on the enthusiasm of students to learn which of course will improve students' learning outcomes (Batubara, 2017; Schneider et al., 2018). Based on the assessments that have been carried out by experts, teachers and students, the next step is to improve the learning media products according to the comments and suggestions given in the product assessment so as to produce sparkol videoscribe-based learning media products that are ready to be disseminated.

The results of this study have several implications, namely (1) The production of a sparkol videoscribe based learning media product on the topic of ecosystems with very good qualifications so that it makes it easier for students to understand learning materials, especially ecosystem topics. (2) With the existence of sparkol videoscribe based learning media on the topic of the teacher ecosystem, it will be easier to convey learning material and motivate teachers to create creative and innovative learning media. In addition, there are the advantages of sparkol videoscribe based learning media products on the developed ecosystem topic, namely displaying short and interesting learning media, especially on the topic of ecosystems where there are no sparkol videoscribe based learning media products on the ecosystem topic on that topic. In addition, learning media products based on sparkol videoscribe on the topic of the developed ecosystem have the advantage of an interesting way of delivering learning which is equipped with dubbing that is not boring and appropriate background music. However, there are deficiencies in the development of sparkol videoscribe-based learning media products on the developed ecosystem topic, namely the implementation of sparkol videoscribe-based learning media products on the ecosystem topic has not been implemented so it is suggested to other researchers to be able to continue this research and produce sparkol-based learning media products. videoscribe on other topics.

\section{CONCLUSION}

Learning media based on sparkol videoscribe on the topic of Ecosystem Class V Elementary Schools are in accordance with the stages of the 4D development model and are declared feasible based on the results of validity tests on aspects of subject content, aspects of learning design, aspects of learning media, trials by teachers and individual trials and small groups. Thus the product of sparkol videoscribebased instructional media on the topic of Class V Elementary School Ecosystems is suitable for use in the learning process.

\section{REFERENCES}

Adabiyah, K., \& Agustina, P. E. (2018). Videoscribe Sebagai Media Pembelajaran Tentang Makhluk Hidup Dan Lingkungannya Pada Siswa Kelas Iv Sd. Kip E-Proceeding, 1, 17-27. https://jurnal.unej.ac.id/index.php/fkip-epro/article/view/9361.

Afifah, N., \& Hidayat, B. (2018). Pengembangan Media Pembelajaran Berbasis Videoscribe pada Materi Sejarah Kerajaan Islam Sumatra dan Akulturasinya Kelas X SMA Muhammadiyah 1 Metro. Jurnal Swarnadwipa, 2(3), https://www.ojs.ummetro.ac.id/index.php/swarnadwipa/article/view/889.

189-200.

Agung, A. A. G. (2014). Metodologi Penelitian Pendidikan. Aditya Media Publishing.

Agung, A. A. G. (2017). Metodologi Penelitian Kuantitatif. Undiksha Press.

Andriana, E., Ramadayanti, S., \& Noviyanti, T. E. (2020). Pembelajaran Ipa Di Sd Pada Masa Covid 19. $\begin{array}{llll}\text { Prosiding Seminar Nasional Pendidikan } & \text { FKIP, }\end{array}$ https://jurnal.untirta.ac.id/index.php/psnp/article/view/9961.

Arywiantari, D., Agung, A. A. G., \& Tastra, I. D. K. (2015). Pengembagan Multimedia Interaktif Model 4D pada Pembelajaran IPA di SMP Negeri 3 Singaraja. Jurnal Edutech Undiksha, 3(1), 1-12. http://dx.doi.org/10.23887/jeu.v3i1.5611.

Asih Nur Azizah. (2018). Pengembangan Media Pembelajaran Sparkol Videoscribe dalam Meningkatkan Minat Belajar Siswa pada Mata Pelajaran Ekonomi Materi Perdagangan Internasional di SMA Batik 2 Surakarta. Kreano, Jurnal Matematika Kreatif-Inovatif, 8(2). https://doi.org/10.15294/kreano.v8i2.10014.

Batubara, H. H. (2017). Pengembangan Media Pembelajaran Matematika Berbasis Android untuk Siswa SD/MI. Muallimuna: Jurnal Madrasah Ibtidaiyah, 4(1), 12-27. http://dx.doi.org/10.31602/muallimuna.v3i1.952.

Dewi, W. A. F. (2020). Dampak COVID-19 terhadap Implementasi Pembelajaran Daring di Sekolah Dasar. Edukatif: Jurnal Ilmu Pendidikan, 2(1), 55-61. https://doi.org/10.31004/edukatif.v2i1.89.

Fadilah, N. (2016). Penerapan Strategi Think Talk Write dalam Meningatkan Kemampuan Berbahasa Anak Tunarungu.

JASSI_anakku,

$18(2)$

13-19. 
https://ejournal.upi.edu/index.php/jassi/article/view/5749.

Syafri, F. S. (2019). Pengembangan Modul Pembelajaran Aljabar Elementer di Program Studi Tadris Matematika IAIN Bengkulu. CV. Zigie Utama.

Fransisca, I. (2018). Pengembangan Media Pembelajaran Video Berbasis Sparkol Videoscribe Pada Pelajaran Ipa Dalam Materi Tata Surya Kelas VI SD. Jurnal Penelitian Pendidikan Guru Sekolah Dasar, 6(11). pgsd/article/view/24661.

Handayani, N. A. (2021). Analisis Pembelajaran IPA Secara Daring pada Masa Pandemi Covid-19. Jurnal Pendidikan Sains Indonesia, 9(2), 217-233. https://doi.org/10.24815/jpsi.v9i2.19033.

Harapan, S. (2020). Identifikasi Kreativitas Siswa Terhadap Mata Pelajaran IPA. Integrated Science Education Journal (ISEJ), 1(1), 16-22. https://doi.org/10.37251/isej.v1i1.21.

Herlin, Suryani, E., \& Kenedy, J. (2020). Pengembangan Media Pembelajaran Berbasis Sparkol Videoscribe Pada Mata Pelajaran Ekonomi Kelas XI IPS di SMA Negeri 2 Sumbawa Besar Tahun 2019. PROSIDING SEMINAR NASIONAL IPPeMas 2020, 1(2), 752-759. http://ejournallppmunsa.ac.id/index.php/ippemas2020/article/view/263.

Hillmayr, D., Ziernwald, L., Reinhold, F., Hofer, S. I., \& Reiss, K. M. (2020). The Potential of Digital Tools to Enhance Mathematics and Science Learning in Secondary Schools: A Context-Specific MetaAnalysis. Computers \& Education, 153(103897), 1-25. https://doi.org/10.1016/j.compedu.2020.103897.

Jowsey, T., Foster, G., Cooper-loelu, P., \& Jacobs, S. (2020). Blended Learning Via Distance in Preregistration Nursing Education: A Scoping. Nurse Education in Practice, 44, 1-8. https://doi.org/10.1016/j.nepr.2020.102775.

Kaffenberger, M. (2021). Modelling The Long-run Learning Impact Of The Covid-19 Learning Shock: Actions to (more than) Mitigate Loss. International Journal of Educational Development, 81, 1-8. https://doi.org/10.1016/j.ijedudev.2020.102326.

Kurniawan, T. D., \& Trisharsiwi. (2016). Pengaruh Penggunaan Media Video Pembelajaran Terhadap Prestasi Belajar Ilmu Pengetahuan Sosial Siswa Kelas V SD Se-Kecamatan Gedangsari Gunungkidul Tahun Ajaran 2015/2016. Trihayu: Jurnal Pendidikan Ke-SD-An, 3(1), 75-89. https://doi.org/10.30738/trihayu.v3i1.739.

Kustandi, C., \& Sutipto, B. (2013). Media Pembelajaran: Manual dan Digital. Ghalia Indonesia.

Latifah, N., Hasan, N., \& Fitria, Y. A. (2020). Pengembangan Media Pembelajaran Sparkol Videoscribe Terhadap Keterampilan Menulis Siswa Kelas VI Sekolah Dasar Negeri Sukamurni 1 Kabupaten $\begin{array}{lllll}\text { Tanggerang. Jurnal } & \text { Madrasah }\end{array}$ http://dx.doi.org/10.31602/muallimuna.v6i1.3463.

Loren, F. T. A. (2017). The use of learning media on listening skill in teaching Indonesian to speakers of other language (TISOL). Lingua Didaktika: Jurnal Bahasa Dan Pembelajaran Bahasa, 11(1), 1-12. https://doi.org/10.24036/ld.v11i1.7625.

Miani, P., Kille, T., Lee, S.-Y., Zhang, Y., \& Bates, P. R. (2021). The Impact of the COVID-19 Pandemic on Current Tertiary Aviation Education and Future careers: Students' Perspective. Journal of Air Transport Management, 94. https://doi.org/10.1016/j.jairtraman.2021.102081.

Muhson, A. (2010). Pengembangan Media Pembelajaran Berbasis Teknologi Informasi. Jurnal Pendidikan Akuntansi Indonesia, 8(2), 1-10.

Nana, S. (2013). Penelitian Hasil Proses Belajar Mengajar. PT Remaja Rosdakarya.

Novita, L., Sukmanasa, E., \& Pratama, M. Y. (2019). Penggunaan Media Pembelajaran Video terhadap Hasil Belajar Siswa SD. Indonesian Journal of Primary Education Penggunaan, 3(2), 64-72. https://doi.org/ 10.17509/ijpe.v3i2.22103.

Nurromah, F., Putra, F. G., \& Farida. (2018). Development of Sparkol Video Scribe Assisted Learning Media. Formatif: Jurnal Ilmiah Pendidikan MIPA, 8(3), 233-250. https://doi.org/10.30998/formatif.v8i3.2613.

Prabowo, S. . (2015). The Effectiveness Of Scientific Based Learning Towards Science Process Skill Mastery Of PGSD Students. Jurnal Pendidikan IPA Indonesia, 4(1), 15-19. https://doi.org/10.15294/jpii.v4i1.3495.

Purwanto, A., Pramono, R., Asbari, M., Santoso, P. B., Wijayanti, L. M., Hyung, C. C., \& Setyowati, R. (2020). Studi Eksploratif Dampak Pendemi COVID-19 Terhadap Pembelajaran Online di Sekolah Dasar. Journal of Education, Psychology and Counseling, 2(1), 1-12. https://ummaspul.ejournal.id/Edupsycouns/article/view/397.

Purwanto, H., Hamka, D., Ramadhani, W., Mulya, D., Suri, F., \& Novalisa, M. (2020). Problematics Study of Natural Sciences (IPA) Online at Junior High School in the Time of the Pandemic Covid-19. International Journal of Progressive Sciences and Technologies (IJPSAT), 21(2), 188-195. 
https://doi.org/10.52155.

Putria, H., Maula, L. H., \& Uswatun, D. A. (2020). Analisis Proses Pembelajaran Dalam Jaringan (DARING) Masa Pandemi COVID-19 pada Guru Sekolah Dasar. Basicedu, 4(4), 861-872. https://doi.org/10.31004/basicedu.v4i4.460.

Qazi, A., Hardaker, G., Ahmad, I. S., Darwich, M., Maitama, J. Z., \& Dayani, A. (2021). The Role of Information \& Communication Technology in Elearning Environments: A Systematic Review. A. Qazi et Al.: Role of ICT in Elearning Environments: A Systematic Review, 9, 45539-45551. https: //doi.org/10.1109/ACCESS.2021.3067042.

Qazi, A., Qazi, J., Naseer, K., Zeeshan, M., Qazi, S., Abayomi-Alli, O., Ahmad, I. S., Darwich, M., Talpur, B. A., Hardaker, G., Nassem, U., Yang, S., \& Haruna, K. (2021). Adaption of Distance Learning to Continue the Academic Year Amid COVID-19 Lockdown. Children and Youth Services Review, 126, 1-6. https://doi.org/10.1016/j.childyouth.2021.106038.

Rahayu, P., Mulyani, S., \& Miswadi. (2012). Pengembangan Pembelajaran IPA Terpau dengan Menggunakan Model Pembelajaran Problem Base melalui Lesson Study. Jurnal Pendidikan IPA Indonesia, 1(1), 63-70. https://doi.org/10.15294/jpii.v1i1.2015.

Samari, S. Y., Sutisnawati, A., \& Amalia, A. R. (2020). Analisis Hasil Belajar IPA Dalam Pembelajaran Daring Di SDN Tanjungsari. JIKAP PGSD: Jurnal Ilmiah Ilmu Kependidikan, 4(3), 227-232. https://doi.org/10.26858/jkp.v4i3.14753.

Schneider, S., Beege, M., Nebel, S., \& Rey, G. D. (2018). A meta-analysis of How Signaling Affects Learning with Media. Educational Research Review, 23, 1-24. https://doi.org/10.1016/j.edurev.2017.11.001.

Silmi, M. Q., \& Rachmadyanti, P. (2018). Pengembangan Media Pembelakaran Video Animasi Berbasis Sparkol Videoscribe Tentang Persiapan Kemerdekaan RI SD Kelas V. JPGSD, 6(4), 486-495. https://jurnalmahasiswa.unesa.ac.id/index.php/jurnal-penelitian-pgsd/article/view/23611.

Triana, D., \& Oktavianto, W. O. (2013). Relevansi Kualifikasi Kontraktor Bidang Teknik Sipil Terhadap Kualitas Pekerjaan Proyek Konstruksi Di Provinsi Banten. Fondasi: Jurnal Teknik Sipil, 2(2), 182190. http://dx.doi.org/10.36055/jft.v2i2.1732.

Windiyani, T., Novita, L., \& Permatasari, A. (2018). Penggunaan Media Pembelajaran Gambar Fotografi untuk Meningkatkan Hasil Belajar pada Mata Pembelajaran Ilmu Pengetahuan Sosial. Jurnal Pendidikan Sekolah Dasar (JPsd), 4(1), 91-101. https://doi.org/10.30870/jpsd.v4i1.2776. 